\title{
Evaluation of Farmers Socioeconomic Characteristics Influencing Tomato Output in District Peshawar, Khyber Pakhtunkhwa, Pakistan
}

\author{
Sajad Ali ${ }^{1 *}$,Jangraiz Khan $^{2}$,Arshadullah Jadoon ${ }^{3}$, Muhammad Riaz ${ }^{4}$ and Abid Khan ${ }^{1}$
}

${ }^{1}$ Sarbad University of Information and Technology Peshawar, Khyber Pakbtunkbwa, Pakistan; ${ }^{2}$ City University of Science and Technology, Peshawar, Khyber Pakhtunkhwa, Pakistan; ${ }^{3}$ School of Economics, Northeast Normal University Jilin, Changchun, China; ${ }^{4}$ Sarhad University of Information and Technology, Peshawar, Khyber Pakhtunkhwa, Pakistan.

Abstract | Tomato (Lycopersicon esculentum L.) is one of the most important and widely distributed horticultural vegetable crops in the world. It is economically attractive to farmers, due to its short duration for ripping which increases productivity. Thus, it is becoming an indispensable source of farmer's income in Pakistan. The production of tomato has been decreased considerably during the last five years. The present study has been conducted to explore the farmer's socio-economic characteristics, affecting the tomato production in district Peshawar, Khyber Pakhtunkhwa, Pakistan. A multi-stage-sampling technique and interview method were adopted for data collection. A sample of 160 tomato (Kharif) growers was drawn from 16 villages of district Peshawar. Chi-Square and Pearson Rank correlation tests were employed to find out the association and correlation between level of productivity and socio-economic characteristics of tomato growers such as education level, work involvement, family size, farming experience, age, and source of income and land size. The results showed a highly significant positive relationship of tomato production with all socio-economic factors except female involvement in the study area. Therefore, extension services and training should be fortified through extension agents for those farmers having no basic education for improving their skills and production of tomato, in turn it will contribute the demands of tomato at provincial and national level.

Received | June 22, 2020; Accepted | July 09, 2020; Published | August 11, 2020

*Correspondence | Sajad Ali, Sarhad University of Information and Technology Peshawar, Khyber Pakhtunkhwa, Pakistan; Email: sajadali1879@ gmail.com

Citation | Ali, S., J. Khan,A. Jadoon, M. Riaz and A. Khan. 2020. Evaluation of farmers socioeconomic characteristics influencing tomato output in district Peshawar, Khyber Pakhtunkhwa, Pakistan. Sarbad Journal of Agriculture, 36(3): 894-899.

DOI | http://dx.doi.org/10.17582/journal.sja/2020/36.3.894.899

Keywords | Tomato crop, Socioeconomic characteristics, District Peshawar, Chi-square test, Pearson rank correlation

\section{Introduction}

$\mathrm{T}$ omato (Lycopersicon esculentum L.) is one of the most important and widely distributed horticultural vegetable crops in the world. It is also (Lycopersicon esculentum L.) an important cash crop, ranked second after potato globally (Adalid et al., 2004). It belongs to the family of potato, eggplant, tobacco and peppers known as Solanaceae family and has vitamins A, B and C (Naika et al., 2005). This crop is economically attractive due to ripe in short duration, leading to its high productivity rate among farmers. Its production has increased about 300\% in last four decades in the world given its economic and nutritive importance (Atherton and Rees, 2005). Approximately 130 million tons of tomatoes were produced in the world in 2008 with China being the largest producer, accounting for about one quarter of the global output, followed by the United States and Turkey (Atherton and Rees, 2005). Tomatoes are major contributors of the carotendiondes (specially lycopene), phenolic and vitamin $\mathrm{C}$ in daily diets 
(Causses et al., 2003). Moreover, results from the epidemiological studies have shown that tomato and its products may have a positive effect against various forms of cancer, especially prostate cancer and cardiovascular diseases (Ellinger et al., 2006).

Tomato crop is grown twice in a year in all provinces of Pakistan, one is cultivated in spring and other is cultivated in autumn. During 2017-18, total production of tomato crop was 414645 tons grown over an area of 41731 hectares. It was cultivated in Punjab, Sindh, Baluchistan and Khyber Pakhtunkhwa (KP) on areas of 8274, 24968, 5354, 3135 hectares respectively in 2017-018 and production was 109445, 182198, 37556, 85446tons respectively (GoP, 2018).

Many factors such as climate, soil type, market, inputs used and economic situation can affect tomato productivity depends (Toenniessen et al., 2008). However, socio-economic factors are also known to power agricultural productivity, mostly among smallholder farmers in terms of quantity and quality of agricultural production (A1-Shadiadeh, 2012).

Enete and Okon (2010) found that socio-economic characteristic like farmers education, fertilizers application, farmers income and seed rate significantly affect agriculture productivity in Nigeria. Further, Ozor and Cynthia (2010) argued that basic education and family size of the farmers were the key socioeconomic characteristics of agriculture productivity. Similarly, Opara (2010) and (Abu et al., 2011) also concluded that basic formal education was the main source of higher agriculture productivity in Nigeria agriculture. Adenuga et al. (2013) investigated that tomato productivity was influenced by education level of the farmers. Besides that, Mathenge and Tschirley (2008) found that agriculture productivity increased with the increase in the income level of the farmers. Khan and Ghafar (2013) revealed that shortage of land is the responsible factor of tomato productivity in Peshawar, Pakistan.

Peshawar is one of the ten tomato producing districts of Khyber Pakhtunkhwa province. Tomato crop is cultivated in two seasons, one is cultivated in spring (Kharif season) and the other is in autumn (Rabi season) in district Peshawar. During Rabi season 2013-14, total production was 1056 tons grown over 93 hectares of area while in Kharif season, tomato was cultivated on an area of 42 hectares having total production of 9524 tons (GoKP, 2014). As tomato production is an important source of income for the farmers, it is, therefore necessary to find-out its determinants. The aim of this paper is to investigate the existence of relationship in tomato productivity and socio-economic characteristics of farmers in district Peshawar.

\section{Materials and Methods}

\section{Data collection}

This research was carried out in district Peshawar of Khyber Paktunkhwa, Pakistan. A multi-stagesampling technique and interview method were used for data collection. District Peshawar is divided administratively in four towns known as tehsil in local dialect i.e. Town-I, Town-II, Town-III and Town IV. Out of which, Town-II and Town-IV were selected on the basis of rural population. In these two towns, three Union Councils were selected on the basis of tomato production. Out of six cells (union councils), three villages were selected from each selected union councils on the purpose of dominating tomato production. From total of eighteen villages, 160 tomato growers were randomly interviewed in August-September 2019. Tomato productivity is divided into three categories on the basis of tomato yield per hectare. These categories are low level (less than 5.0 tons $\mathrm{ha}^{-1}$, medium level (5.0-10.0 tons/ hectare) and high level (above 10.0 tons ha ${ }^{-1}$ ).

\section{Analytical technique}

Descriptive statistics were employed to analyze the socio-economic characteristics of tomato growers. In addition, Chi-square and Spearman Rank Correlation were employed to test the association and correlation between various categories of tomato productivity and socio-economic characteristics of tomato growers. The Chi-square statistic is computed as (Masood et al., 2012)

$$
\chi^{2}=\Sigma \Sigma\left(o_{i j}-e_{i j}\right)^{2} / e_{i j} \text { with }(r-1)(c-1) \text { degree of freedom }
$$

Where;

$$
\begin{aligned}
& e_{i j}=\left(A_{i}^{*} B_{j}\right) / n=\left(i^{\text {th }} \text { row total } l^{*} J^{\text {th }}\right. \text { Colum total) /Total } \\
&\text { number of observation })
\end{aligned}
$$

The Spearman Correlation is computed is as:

$$
r s=1-\frac{6 \Sigma d^{2}}{n\left(n^{2}-1\right)} \quad(\text { Kazmi, 2015) }
$$

Where;

$d_{i}=$ difference ranks of between corresponding values 
of categorical variables, $n=$ Number of data points of the two categorical variables. The value of spearman correlation coefficient $(r)$ lie between -1 and +1 .

\section{Results and Discussion}

\section{Socioeconomic factors of tomato farmers}

The results show different socioeconomic characteristics of tomato growers in the study area. According to the results, education level of respondents was mostly up to primary level. $31 \%$ of the respondents were illiterate, and $28 \%$ had education up to primary level while $40 \%$ were above the primary level. This indicates that majority of the farmers could not continue their education after primary level and joined farming profession as a source of income. In term of work involvement, results shows that about $44 \%$ females were involved to help their males. In case of family size having 4-6 members were about $40 \%$ followed by $30 \%$ having members between $6-8$. It indicates that higher family size implies higher farm laboring. It was evident from the Table 1 that most of the tomato growers were aged and experienced (42\% in the age group of $41-60$ and $50 \%$ having more than 10 years' experience in tomato production). The results shown in Table 1 that tomato production was the main source of income of $37 \%$ respondent followed by the about $44 \%$ respondent having tomato and livestock. Finding shows that $50 \%$ of the farmers have farm size less than 0.5 hectare while only $8 \%$ holding more than 1.0 hectare in the study area.

\section{Relationship between socio-economic of tomato growers and different productivity levels}

The Table 2, presents the association and correlation among the tomato productivity level and different socio-economic characteristics of tomato growers in the study area. The findings as shown in the Table 2 shows a significance difference between the tomato productivity level and socioeconomic characteristics. Results show that educational level has a significant association and correlation with tomato productivity. Farmers with low level of education were lagged behind (only 10\%) the farmers with high level of education (53\%) in tomato productivity. The results were similar to Masood et al. (2012).

Results reveled that both female involvement and family size were statistically significant at $5 \%$ significant level $\left(\chi^{2}=2.06476 .03 \mathrm{~d} . \mathrm{f}=2 \mathrm{P}\right.$-value $=0.002$ and $\chi^{2}=164.89 \mathrm{~d} . \mathrm{f}=6 \mathrm{P}$-value $\left.=0.000\right)$. It implies that less female involvement and small family size, less will be tomato productivity.
Table 1: Socio-economic factors of tomato farmers.

Socio-economic factors

Frequency (N) Percentages (\%)

Educational status (ES)

$\begin{array}{lll}\text { Illiterate } & 50 & 31.25 \\ \text { Primary level } & 45 & 28.12 \\ \text { Above primary } & 65 & 40.62 \\ \text { Total } & 160 & 100\end{array}$

\section{Work involvement}

$\begin{array}{lll}\text { Male } & 90 & 56.25 \\ \text { Female } & 70 & 43.75 \\ \text { Total } & 160 & 100\end{array}$

Family size (FS) (No.)

$\begin{array}{lll}0-3 & 20 & 12.50 \\ 4-6 & 63 & 39.37 \\ 7-10 & 47 & 29.37 \\ \text { Above } 10 & 30 & 18.75 \\ \text { Total } & 160 & 100 \\ \text { Farmers experience (years) } & \\ <5 & 30 & 18.75 \\ 6-10 & 50 & 31.25 \\ >10 & 80 & 50.00 \\ \text { Total } & 160 & 100\end{array}$

Age of respondent (years)

$\begin{array}{lll}\text { Below } 25 & 20 & 12.50 \\ 25-40 & 63 & 39.37 \\ 41-60 & 67 & 41.87 \\ \text { Above } 60 & 10 & 6.25 \\ \text { Total } & 160 & 100\end{array}$

\section{Source of income}

Tomato production $\quad 60$

37.50

Tomato and livestock $\quad 70$

43.75

Employment

12.25

Others

20

6.25

Total

160

100

Land size (ha.)

$\begin{array}{lll}<0.5 & 80 & 50.00 \\ 0.5-1.0 & 67 & 41.87 \\ >1.0 & 13 & 8.125 \\ \text { Total } & 160 & 100\end{array}$

Farming experience determines the efficiency of performing a task to get high productivity level. The results show that high level of productivity were observed from 30 (50\%) farmers who have more than ten years' experience tomato production and the relationship between the variables was found statistically significant. 
Table 2: Relationship between socio-economic of tomato growers and different productivity levels.

\begin{tabular}{|c|c|c|c|c|}
\hline \multirow{2}{*}{$\begin{array}{l}\text { Socio-econom- } \\
\text { ic factors }\end{array}$} & \multicolumn{4}{|c|}{ Different tomato productivity level } \\
\hline & Low & Medium & High & \\
\hline $\begin{array}{l}\text { Educational } \\
\text { status (ES) }\end{array}$ & Total & & & \\
\hline Illiterate & $27(64.28)$ & $13(22.41)$ & $10(16.63)$ & $50(31.2$ \\
\hline Primary level & $10(23$ & $17(29.31)$ & $18(30.00)$ & $45(28.1$ \\
\hline Above primary & $05(11.91)$ & $28(48.27)$ & $32(53.33)$ & $65(40.62$ \\
\hline Total & $42(100)$ & $58(100)$ & $60(100)$ & $160(100$ \\
\hline \multicolumn{5}{|c|}{$\begin{array}{l}\text { Chi }-\mathrm{Sq}=32.996 \text { d. } \mathrm{f}=4 \mathrm{P}-\text { value }=0.000, \text { Spearman Rank } \\
\text { Correlation }=0.391 \text {, Sig. }=0.000\end{array}$} \\
\hline \multicolumn{5}{|c|}{ Female involvement } \\
\hline Yes & $15(35.71)$ & $25(43.10)$ & $30(50.00)$ & $70(43.75$ \\
\hline No & $27(64.28)$ & $33(56.90)$ & $30(50.00)$ & $90(56.2$ \\
\hline Total & $42(100)$ & $58(100)$ & $60(100)$ & $160(100$ \\
\hline
\end{tabular}

Chi-Sq $=2.06476 .03$ d.f $=2$ P-value $=0.002$, Spearman Rank Correlation $=-0.113$,Sig. $=0.003$

Family size (FS) (Nos.)

$\begin{array}{lllll}0-3 & 11(21.27) & 6(24.53) & 3(16.67) & 20(12.50) \\ 4-6 & 19(59.57) & 27(37.74) & 17(25.00) & 63(39.37) \\ 7-10 & 10(14.89) & 17(18.87) & 20(30.00) & 47(29.37) \\ \text { Above } 10 & 02(4.25) & 8(9.43) & 20(28.33) & 30(18.75) \\ \text { Total } & 42(100) & 58(100) & 60(100) & 160(100)\end{array}$

Chi-Sq $=164.89$ d.f $=6$ P-value $=0.000$,Spearman Rank Correlation $=0.853$, Sig. $=0.000$

Farmers experience (years)

$\begin{array}{lllll}<5 & 18(42.85) & 8(13.79) & 4(6.66) & 30(18.75)\end{array}$

6- $10 \quad 14(33.33) \quad 10(17.22) \quad 26(43.33) \quad 50(31.25)$

$\begin{array}{lllll}\text { Above } 10 & 10(23.81) & 40(68.96) & 30(50.00) & 80(50.00)\end{array}$

$\begin{array}{lllll}\text { Total } & 42(100) & 58(100) & 60(100) & 160(100)\end{array}$

Chi-Sq $=166.58$ d.f $=4$ P- value $=.000$, Spearman Rank Corre lation $=0.842$, Sig. $=0.000$

Source of income

Tomato produc- 25(59.52) $23(39.65) \quad 12(20.00) \quad 60(37.50)$ tion

$\begin{array}{lllll}\text { Tomato and } & 15(35.71) & 30(51.72) & 25(41.67) & 70(43.75)\end{array}$ livestock

Employment $\quad 6(14.29) \quad 3(5.17) \quad 11(18.33) \quad 20(12.25)$

$\begin{array}{lllll}\text { Others } & 0(0.00) & 2(3.5) & 8(13.33) & 10(6.25)\end{array}$

Total $\quad 42(100) \quad 58(100) \quad 60(100) \quad 160(100)$

Chi-Sq $=154.31$ d.f $=6$ P-value $=0.000$,Spearman Rank Correlation $=0.833$, Sig. $=0.000$

Farmers age (years)

$\begin{array}{lllll}\text { Below } 25 & 14(33.33) & 6(10.34) & 0(00.00) & 20(12.50)\end{array}$

25-40 13(30.95) $24(41.37) \quad 26(43.33) \quad 63(39.37)$

$\begin{array}{lllll}41-60 & 9(21.42) & 25(43.10) & 33(55.00) & 67(41.87)\end{array}$

$\begin{array}{lllll}\text { Above } 60 & 6(14.28) & 3(5.17) & 1(1.67) & 10(6.25) \\ \text { Total } & 42(100) & 58(100) & 60(100) & 160(100)\end{array}$

Chi-Sq $=154.31$ d.f $=6$ P-value $=0.000$,Spearman Rank Correlation $=0.833$, Sig. $=0.000$

Land size (ha.)

$\begin{array}{lllll}<0.5 & 36(85.71) & 20(34.48) & 24(40.00) & 80(50.00)\end{array}$

$\begin{array}{lllll}0.5-1.0 & 4(9.52) & 31(53.45) & 32(53.33) & 67(41.87)\end{array}$

$\begin{array}{lllll}>1.0 & 2(4.76) & 7(12.07) & 4(6.67) & 13(8.125)\end{array}$

Total $\quad 42(100) \quad 58(100) \quad 60(100) \quad 160(100)$

Chi-Sq $=219.8112 .850$ d.f $=4$ P- value $=.000$, Spearman Rank Correlation $=0.776$, Sig. $=0.000$

Note: Figures in parenthesis show percentages.

The results shown in Table 2 reflect that almost $80 \%$ of the respondent having tomato production as a main source of income and shows a significant relationship with productivity level. It implies that tomato production was the main source of income of the farmers in the study area. Results in Table 2 reveals that $40 \%$ farmers having less 0.5 hectares producing high level of tomato productivity while only about $7 \%$ producing the same level having above 1 hectare. The relationship between variables was found significant at $\mathrm{P}=0.000$

\section{Conclusions and Recommendations}

Socioeconomic characteristics of tomato growers were deliberated arrangement of educational status, female involvement, family size, and farmer's experience, main source of income and size of land. Most of the factors reveal significant association and correlation with productivity level. Interestingly female involvements shows an insignificant correlation with tomato productivity level $\left(r_{\mathrm{s}}=-0.113\right.$, Sig. $\left.=0.153\right)$.

- Extension services should be fortified through extension agents for those farmers having no basic education to improve their skills.

- The tomato growers should be trained and encouraged by the regular visits of extension agents to apply approved agronomic practices.

- Tomato growers should be mobilized for agriculture credit to meet the cost of inputs such as improved seeds, agrochemicals and fertilizers etc.

- Tomato growers should be mobilized to form groups and their own markets to establish a markets network to enable them to access reliable markets. 
Novelty Statement

This research provides insight of tomato growers for boosting production and evaluated influence of the farmer's socioeconomic characteristics by employing Chi Square and Spearman Rank Correlation approach on tomato production in district Peshawar, KP.

\section{Author's Contribution}

Sajad Ali: Principal author, who conducted research, experiments and wrote 1st draft of the manuscript.

Jangraiz Khan: Helped in analysis of data and interpretation. Refined the paper.

Arshad Ullah Jadoon: Helped in materials and methods

Muhammad Riaz: Helped in overall format and proofreading.

Abid Khan: Helped in field work data collec-tion and questionnaire development

\section{Conflict of interest}

The authors have declared no conflict of interest.

\section{References}

Abu, O., M. Alumunku and P.T. Tsue. 2011. Can small-scale tomato farmers flourish in Benue State, Nigeria.J.Agric. Sci., 2(2): 77-82. https:// doi.org/10.1080/09766898.2011.11884670

Adalid, A.M., S. Rosello and F. Nuez. 2004. Breeding tomatoes for their high nutritional value. Rec. Res. Dev. P1. Sci., 2: 33-52.

Adenuga, A.H., A. Muhammad-Lawaland O.A. Rotimi, 2013. Economics and technical efficiency of dry season tomato production in selected areas in Kwara State, Nigeria. Agris online Papers in Eco. Inform., 5(1):11-19.

Al-Shadiadeh, A.N., F.M. AL-Mohammady and T.R. Abu-Zahrah. 2012. Factors influencing adoption of protected tomato farming practices among farmers in Jordan Valley. World Appl. Sci. J., 17(5): 572-578.

Atherton, J. and A. Rees. 2005. Tomatoes. Crop Production Science in Horticulture Series. CABI publishing, CAB International Wallingford UK.

Causse, M., M. Buret, K. Robini and P. Verschave. 2003. Inheritance of nutritional and sensory quality traits in fresh market tomato and relation to consumer preferences. J. Food Sci., 68: 2342-2350. https://doi. org/10.1111/j.1365-2621.2003.tb05770.x

Ellinger, S., J. Ellinger and P. Stehle. 2006. Tomatoes, tomato products and lycopene in the prevention and treatment of prostate cancer: Do we have the evidence from intervention studies? Curr. Opin. Clin. Nutr. Metab. Care. 9(6): 722-727. https://doi.org/10.1097/01. mco.0000247470.64532.34

Enete, A.A. and U.E. Okon. 2010. Economics of water leaf production (Talinum triangulare) In AkwaIbom State, Nigeria. Field Action Science Reports.

Food and Agriculture Organization, 2012. Food and Agriculture Organization of the United Nations for a World without Hunger. http:// faostat.fao.org/default.aspx

GoKP, 2014. Crops Statistics of Khyber Pakhtunkhwa, Crops Reporting Services, Agriculture, Livestock Cooperative Department, Peshawar.

GoP, 2018. Agriculture Statistics of Pakistan. 201718., Area, Production of Fruit, Vegetables and Condiments. Ministry of Food and Agriculture (Economic wing). Islamabad.

Kazmi, S.M.A., 2015. How does socio-economic factors force children into child labour? A case study of Sahiwal District, Punjab, Pakistan. Sustainable Development Policy Institute

Khan, R.E.A. and S. Ghafar. 2013. Technical efficiency of tomato production: A case Study of district Peshawar (Pakistan). World App. Sci. J., 28(10): 1389-1392.

Masood, A., N. Ellahi and Z. Batool. 2012. Causes of low agricultural output and impact on socioeconomic status of farmers: A case study of rural Potohar in Pakistan. Int. J. Basic Appl. Sci., 1(2): 343-351. https://doi.org/10.17142/ ijbas-2012.1.2.21

Mathenge, M.K. and D.L. Tschirley. 2008. Off farm work and farm production decisions: evidence from maize producing households in rural Kenya. http://fsg.afre.msu.edu/kenya / WPS33.pdf

Naika, S., J.L. de Jeude, M. de Goffau, M. Hilmi and B. van Dam. 2005. Cultivation of tomato production. processing and marketing. http:// journeytoforever.org/farmlibrary/AD17.pdf

Opara, U.N., 2010. Personal and socio-economic determinants of agricultural information use by farmers in the Agricultural Development Programme (ADP) zones of Imo State, Nigeria. 
http://unllib.unl.edu/LPP/opara

Ozor, N. and N. Cynthia. 2010. Difficulties in adaptation to climate change by farmers in Enugu State, Nigeria. J. Agric. Ext., 14(2): 106122. https://doi.org/10.4314/jae.v14i2.64127
Toenniessen, G., A. Adesina and J. Vries. 2008. Building an alliance for a green revolution in Africa. Nairobi, Kenya. Ann. N.Y. Acad. Sci., 1136: 233-242. https://doi.org/10.1196/ annals.1425.028 